\title{
THE FISHES OF SEAGRASS COMMUNITY ON THE WEST SIDE OF BURUNG ISLAND (PARI ISLANDS, SERIBU ISLANDS) AND THEIR VARIATIONS IN ABUNDANCE
}

by

MALiKusworo Hutomo $^{1)}$ and Sularto Martosewojo ${ }^{1)}$

\begin{abstract}
Monthly collections of fishes in a seagrass community on the west of Burung Island, Pari Islands, were made from May 1975 to February 1976. Seventy-eight species of fishes were collected. Number of specimens, size range, and modal size are given for each month for each species. Number of species and specimens were found highest in July. Relative and total abundances of the more numerous species are summarized. Apogon margaritophorus was the predominant species in the fish community of the area. Notes on the spawning of Siganus canaliculatus are presented, since this species attracts the attention of many mariculturists. The separation of these fishes into four groups is also discussed.
\end{abstract}

\section{INTRODUCTION}

The seasonal abundance of marine fishes has been the subject of some investigations. GUNTER (1938) has studied this phenomenon in Louisiana; WARFEL \& MERRIMAN (1944) in New England; SPRINGER \& WoOdBuRn (1960) in Tampa Bay, Florida; PEARCY \& RiCHARDs (1962) in Mystic estuary, Connecticut; and SPRINGER \& MC ERLEAN (1962) in South Florida. So far only few studies have been carried out in Indonesian waters. HARDENBERG (1931) conducted a study on the fish fauna of the Rokan river mouth, East Sumatra. His observation, however, was made only within few months. Therefore, the results did not give the community conditions of the whole year. Similar observations were also made in the mouth of Kumai river, Southwest Kalimantan (HARDENBERG 1937).

The present study conducted in a seagrass community of Burung Islands, the Pari Island group, off Jakarta Bay. Seagrass beds form an important ecosystem in the littoral and sublittoral regions. Seagrass is directly fed on by some fishes and other animals, and the seagrass community is an important nursery ground for their juveniles (KIRKMAN 1975). The study is firstly intended to determine the nature and composition

1) National Institute of Oceanology, Indonesian Institute of Sciences, Jakarta, Indonesia. 
of the fish community found in that particular habitat. Secondly, which is more important, is to collect as much as possible data on the smaller inshore species, especially on those species that are commercially important.

\section{MATERIALS AND METHODS}

\section{Description of the area}

The Pari Islands is a pseudo-atoll called the Agennieten Eilanden by the Dutch. It is located about $35 \mathrm{~km}$ northwest of Jakarta, between $05^{\circ} 51^{\prime} 00^{\prime \prime}$ and $05^{\circ} 52^{\prime} 25^{\prime \prime} \mathrm{S}, 106^{\circ} 34^{\prime} 30^{\prime \prime}$ and $106^{\circ} 38^{\prime} 20^{\prime \prime} \mathrm{E}$, at the most southern part of the Seribu Islands - a chain of more than 100 islands extending NNWSSE across the Java Sea (Fig. 1). The Pari Islands consists of five small islands and two large and seven small lagoons (Fig.2).

The site chosen for the present study is a seagrass community on the northwest of Burung Island. The seagrass bed is about $70 \mathrm{~m}$ long and nine metres wide. The maximum depth is $135 \mathrm{~m}$ at low tide.

The seagrass community is dominated by Diplanthera sp., while a small Thalassia bed covers the east end. Enhalus spp. are scarce and mostly grow in the deeper part. During the spring low tide the Thallasia bed is partly exposed. Four genera of algae found in this area wee Am-phiroa, Codium, Padina, and Halimeda. Amphiroa and Codium are relatively more frequent than the others.

A few holothurians, Sinaphta, are scattered throughout the sampling area. Other holothurians which were also recorded are Holothuria atra and $H$. impatients. Considerable number of the common seastar, Archas-ter typicus, were frequently collected during the sampling. Molluscs are scarce, only three genera were observed, those are Pinna, Lambis, and Strombus.

\section{Sampling method}

A small beach seine-net was used for sampling. It consists of two wings, a body, and a bag. The wings are 10 metres long and the ropes are about five metres each. The body of the net is four metres long with gradually decreasing mesh-size toward the cod-end or bag. The bag is three metres long with a holding capacity of $50 \mathrm{kgs}$ of fish.

Sampling was done monthly for a period of 10 months, from May, 1975 to February 1976. Three hauls were made each month. Each was started from the west end, perpendicular to the coastline, ended in the east end and covering the seagrass community. Prior to the actual sam- 
IIIE FISIIIS OF SFAGRASS COMMLNITY

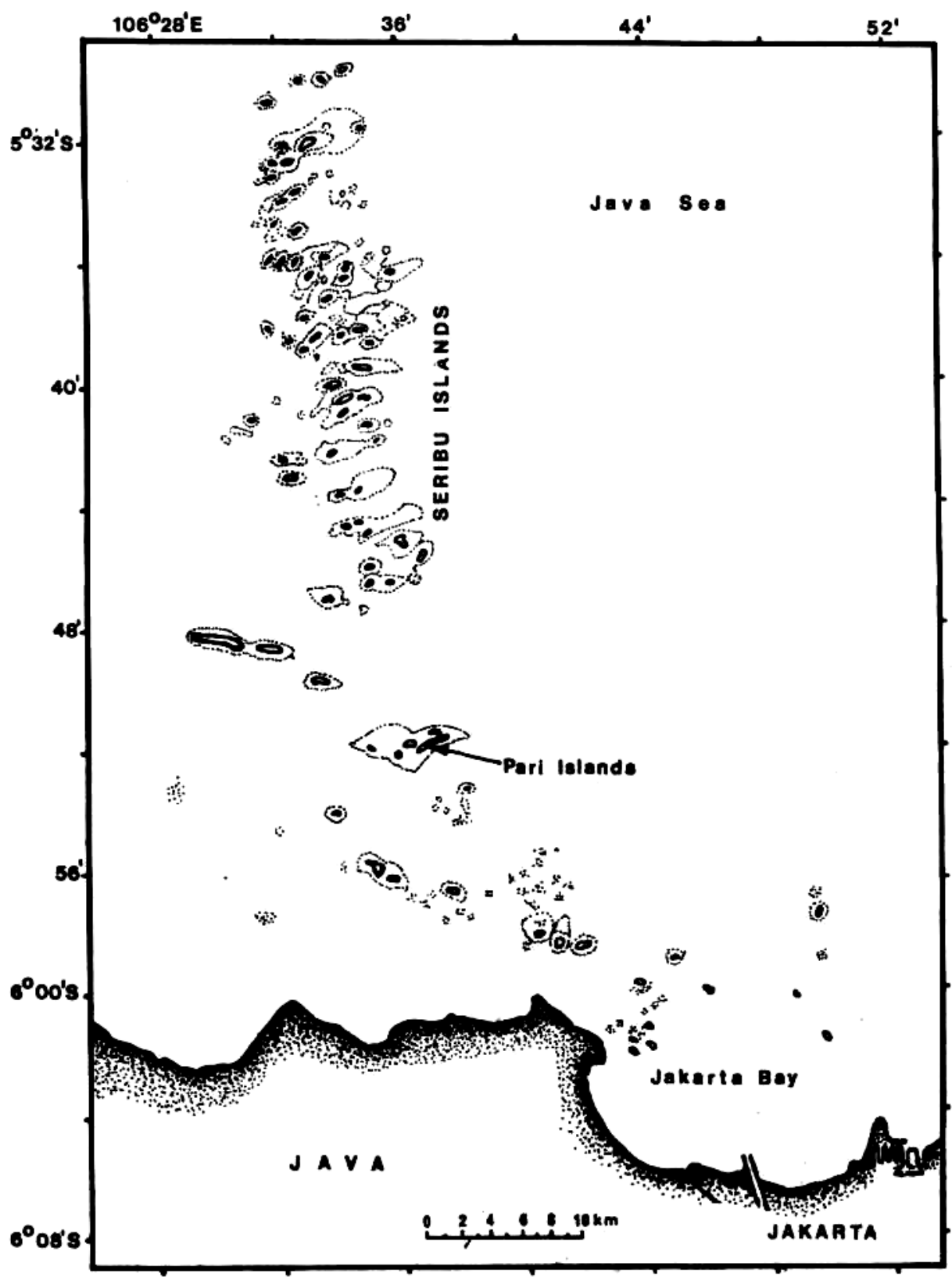

Figure I. Scribu Islands and Jakarta Bay. Pari Islands is indicated by arrow: 
Malikusworo Hutomo \& Sularto Martosewojo

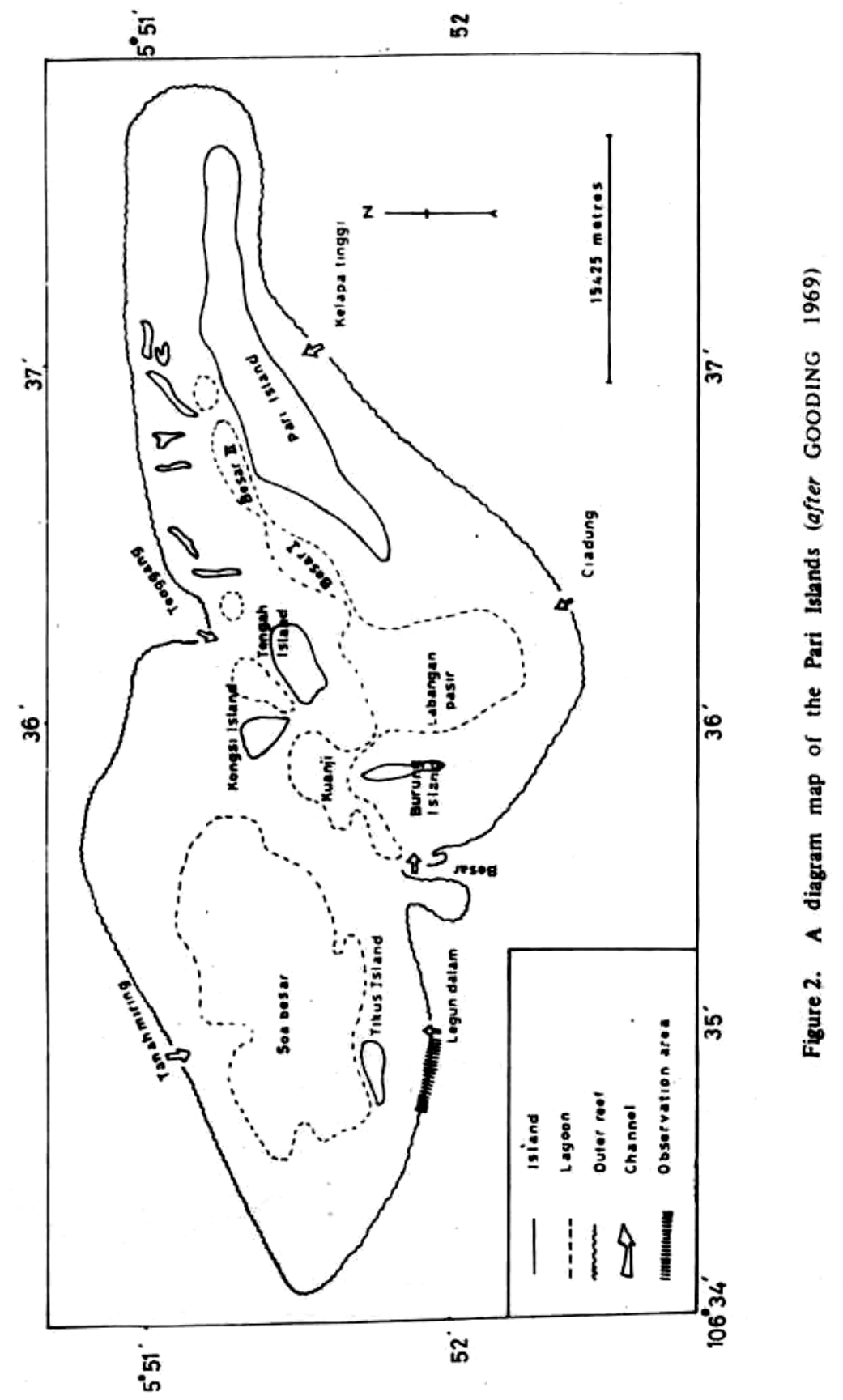


pling, an experiment was carried out in order to determine how many replicates were necessary in order to obtain a representative sample. It was found out that after the third haul no more additional species could be collected. The time required for each haul was about 50 minutes. Since each haul was done in the same area the resulting catches can be considered as to reflect the abundance of the standing crop in the area. All hauls were done in the daytime and during the low tide, as it was determined that sampling during the high tide was not effective.

The samples were preserved in $10 \%$ formalin, specimens were sorted out in laboratory and standard lengths were determined to nearest millimeter using a Mitutoyo dial-caliper. Catches yielding large quantities of individual fishes were subsampled.

\section{Analysis}

The authors followed WARFEL \& MERRIMAN (1944) for the analysis of the abundance of the more numerous species. Two approaches have been used to evaluate the abundance, namely "relative abundance" and "total abundance".

For estimating relative abundance, a system of scoring was devised which facilitated the summarization of the positional rank for each species at different months during its presence in the area. All species in the first ten ranks were assigned a score, the first rank being given 10, the second 9 , the third 8 , and so on until the form in the ten place was assigned a score of 1 . The advantages of this system are its simplicity and that is allows direst comparison between the different species. Total abundance indicates the fluctuations of total numbers collected from month to month.

\section{RESULTANDDISCUSSION}

Seventy-eight species of fishes representing 32 families were collected during this study. Number of specimens, size range, and modal sizes of each species for each month are listed in Appendix I.

The ranks of relative abundance and total abundance of the more numerous species are presented in Table I. Apogon margaritophorus occupies the first rank in relative as well as in total abundance.

The variations of total abundance for all species and number of species are shown in Figure 3. It can be observed that there is a clear peak, both in number of species and in overall total abundance in July and a more or less constant number of species and overall total abundance in the rest of the year. Statistically there is a correlation between the number of individual caught and the number of species (Fig. 4). 


\section{MALIKUSWORO HUTOMO \& SULARTO MARTOSEWOJO}

Table I. Relative and total abundance of the major species of fishes found in the study area.

\begin{tabular}{|c|c|c|c|c|c|}
\hline \multirow[b]{2}{*}{ S p e c i e s } & \multicolumn{2}{|c|}{ Relative Abundance } & \multicolumn{3}{|c|}{ Total Abundance } \\
\hline & Rank & Score & Rank & $\%$ & Number \\
\hline 1. Apogon margaritophorus & 1 & 95 & 1 & 39.07 & 3250 \\
\hline 2. Halichoeres leparensis & 2 & 62 & 5 & 5.41 & 450 \\
\hline 3. Pranaeus duodecimals & 3 & 58 & 3 & 11.01 & 916 \\
\hline 4. Paramia quinquelineata & 4 & 53 & 4 & 5.59 & 465 \\
\hline 5. Gerres macrosoma & 5 & 52 & 6 & 4.83 & 402 \\
\hline 6. Monacanthus tomentosus & 6 & 48 & 8 & 3.91 & 325 \\
\hline 7. Siganus canaliculatus & 7 & 47 & 2 & 13.20 & 1098 \\
\hline 8. Stethojulis strigiventer & 8 & 36 & 9 & 2.62 & 218 \\
\hline 9. Halichoeres argus & 9 & 32 & 10 & 1.77 & 147 \\
\hline 10. Lethrinus spp. & 10 & 22 & 12 & 1.13 & 94 \\
\hline 11. Scarus sp. & 11 & 21 & 11 & 1.15 & 96 \\
\hline 12. Siganus virgatus & 12 & 18 & 13 & 1.11 & 92 \\
\hline 13. Siganus chrysospilos & 13 & 10 & 14 & 0.46 & 38 \\
\hline 14. Apogon sangiensis & 14 & 9 & 7 & 4.16 & 346 \\
\hline 15. Hemiglyphidodon plagio- & & & & & \\
\hline metopon & 15 & 6 & 20 & 0.22 & 18 \\
\hline 16. Chaorodon anchorago & 16 & 5 & 16 & 0.30 & 25 \\
\hline 17. Monacanthus hajam & 17 & 5 & 15 & 0.42 & 35 \\
\hline 18. Leiognathus fasciatus & 18 & 4 & 18 & 0.25 & 21 \\
\hline 19. Lethrinus frenatus & 19 & 4 & 19 & 0.23 & 19 \\
\hline 20. Abudefduf sp. & 20 & 3 & 21 & 0.19 & 16 \\
\hline 21. Pentapodus caninus & 21 & 3 & 17 & 0.29 & 24 \\
\hline 22.. Monacanthus mylii & 22 & 2 & 22 & 0.14 & 12 \\
\hline 23. Mulloides samoensis & 23 & 2 & 25 & 0.10 & 8 \\
\hline 24. Pelates quadrilineatus & 24 & 2 & 24 & 0.11 & 9 \\
\hline 25. Congrogadus subducens & 25 & 1 & 23 & 0.13 & 10 \\
\hline 26. Scolopsis sp. & 26 & 1 & 27 & 0.05 & 4 \\
\hline 27. Tylosurus punctulatus & 27 & 1 & 27 & 0.05 & 4 \\
\hline 28. Parupeneus barberinus & 28 & 1 & 26 & $\mathbf{0 . 0 7}$ & 6 \\
\hline
\end{tabular}


THE FISHES OF SEAGRASS COMMUNITY

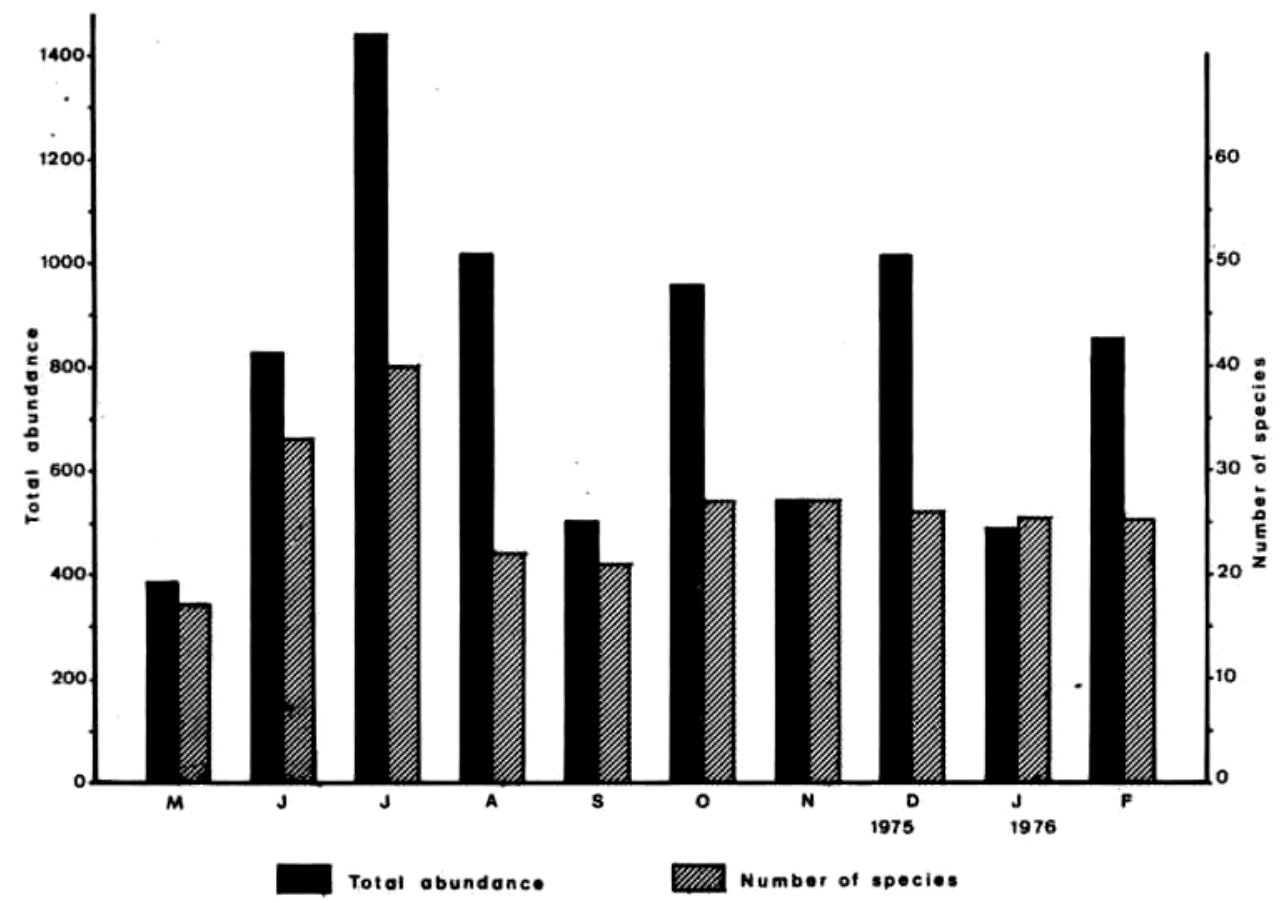

Figure 3. The variations of total abundance and number of species of the fishes of seagrass community on the west side of Burung Island. 


\section{MALIKUSWORO HUTOMO \& SULARTO MARTOSEWOJO}

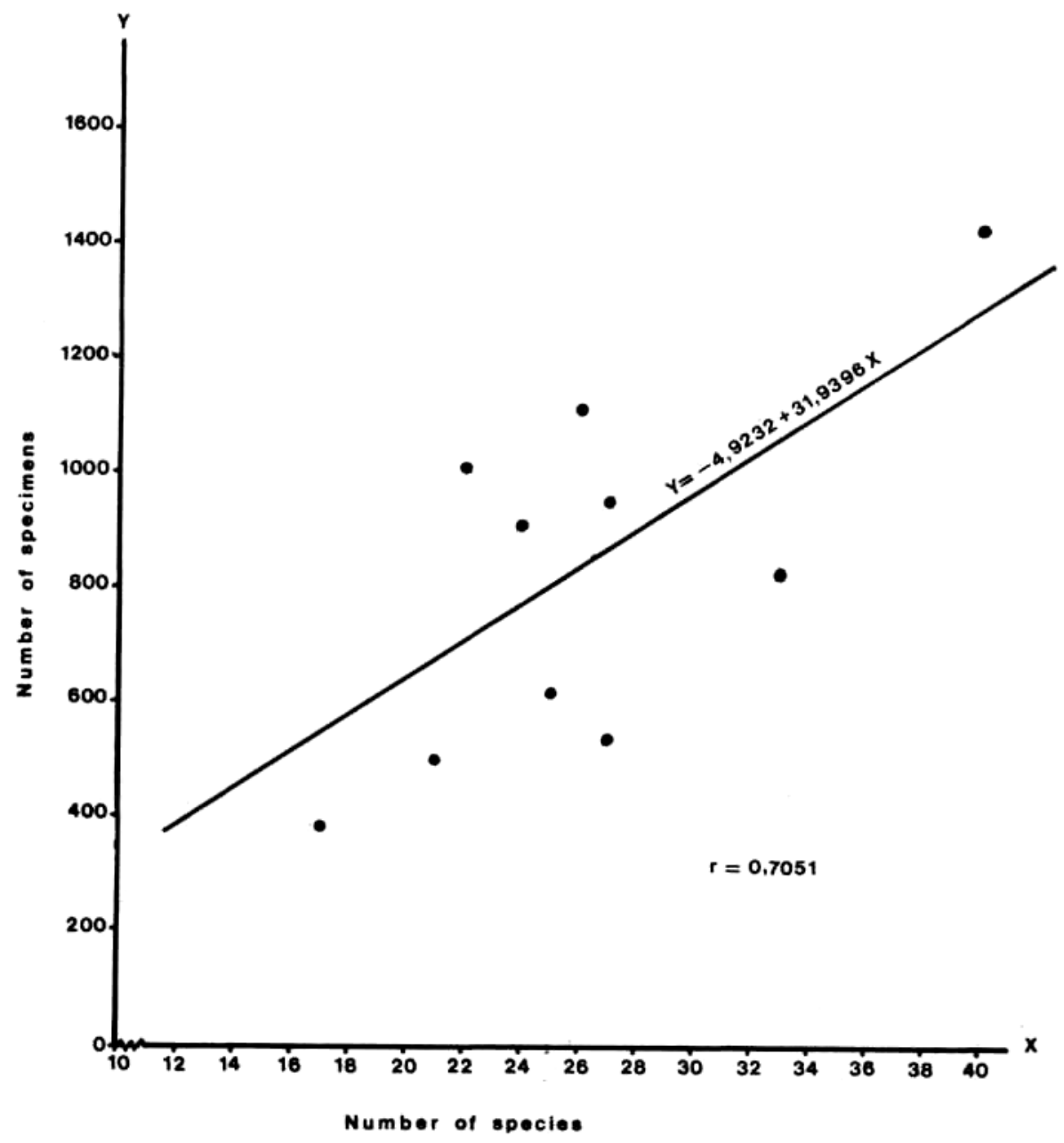

Figure 4. The relationship between number of species and number of specimens of the fishes caught on the west side of Burung Island. 
THE FISHES OF SEAGRASS COMMUNITY

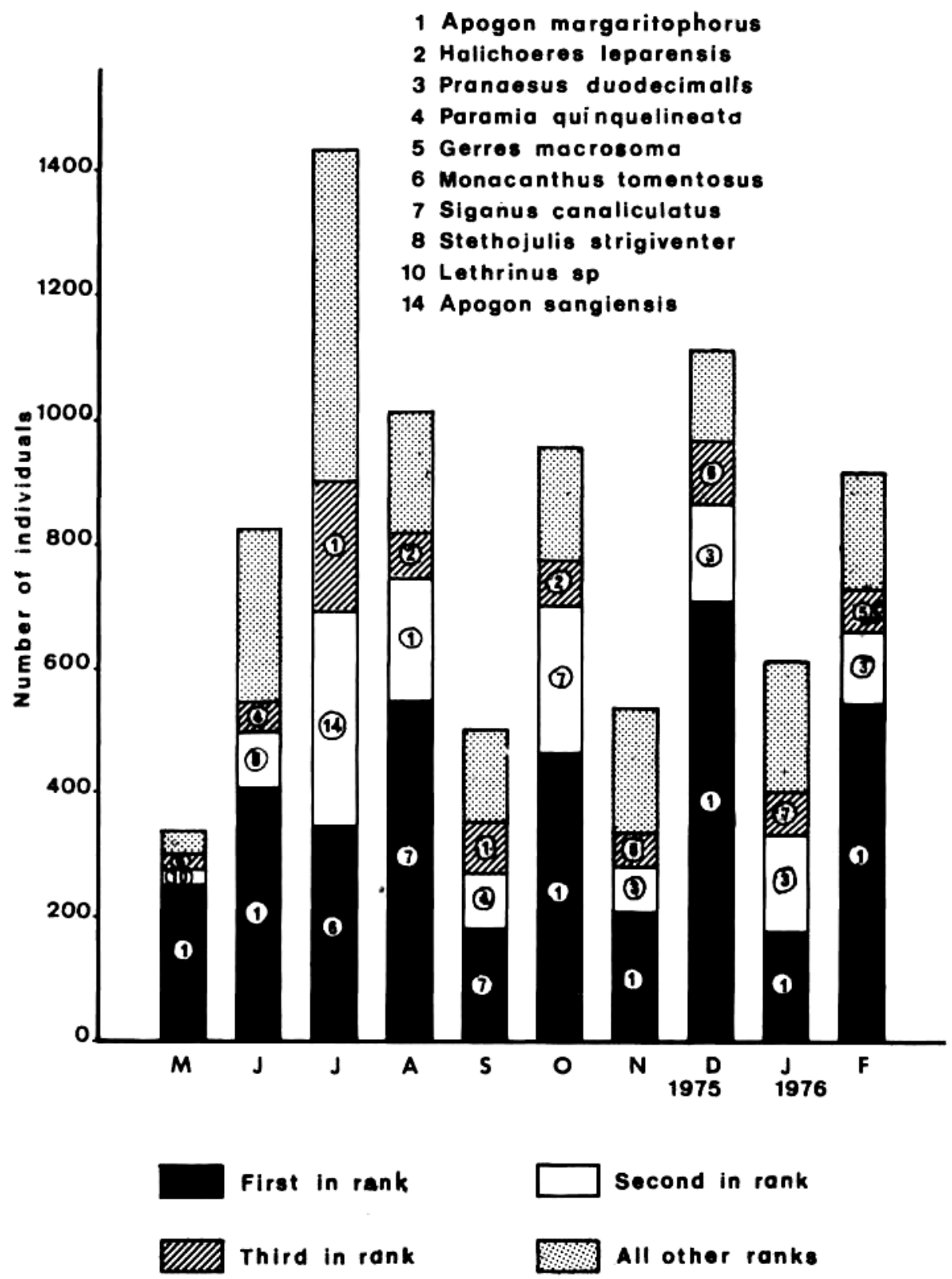

Figure 5. Total abundance of major species by rank. The circled number inside the bar indicates, the species that was dominant in the appropriate rank. 
Figure 5 shows the total abundance of the major species for each month. It is noted that during the period of study the total abundance was largely dominated by Apogon margaritophorus, except in June Monacanthus tomentosus and in July and August Siganus canaliculatus, respectively was predominant. During the east monsoon (May-October), Apogon margaritophorus and Siganus canaliculatus predominated. The next prominent species were Monacanthus tomentosus, Apogon sangiensis, Paramia quinquelineata, Halichoeres leparensis, and Stethojulis strigiventer. During the west monsoon the total abundance was largely determined by $A$. margaritophorus. Next important species were Pranaesus doudeci-malis, Gerres macrosoma, Monacanthus tomentosus, and Siganus canaliculatus.

Among 32 families found in the area, only six families, namely Apogonidae, Atherinidae, Labridae, Gerridae, and Monacanthidae, constitute the major component of the fish community. Variations of those families in percentage of total abundance are shown in Figure 6.

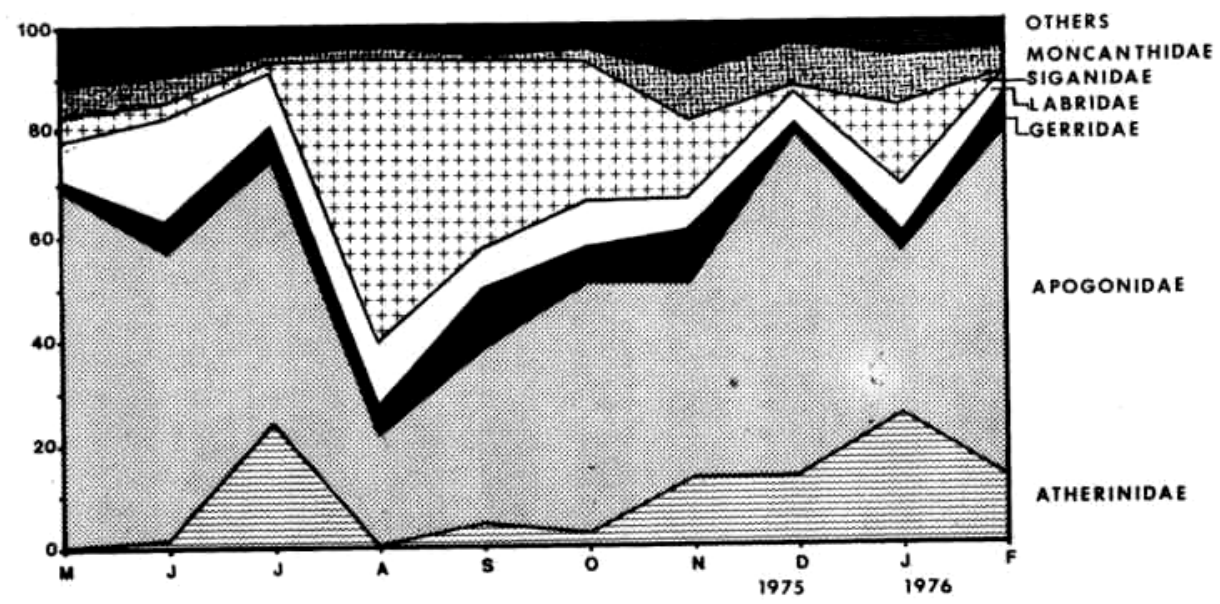

Figure 6. The variations of major components in the fish community of seagrass community on the west side of Burung Island.

Apogonidae is the most predominant family. It is represented by four species, of which Apogon margaritophorus is the most important. It was observed that almost in every haul the specimens consisted of many spent individuals, with some of them keeping the fertilized eggs in their mouths. This fact suggests that this species has a prolonged spawning period and that the area is their spawning ground. Though the juveniles had never been collected, the authors assume that this species is a permanent resident of the area. The absence of the juveniles 
in the collections may be due to their small size, which might prevent them from being retained by the net. The next important species is Paramia quinquelineata, 18-58 $\mathrm{mm}$ in length. A mature specimen can attain a length of $120 \mathrm{~mm}$ (SMITH 1961). From this, it can be assumed that this species lives there before maturity and migrate to another place for spawning. Interesting is also the occurrence of Apogon sangi-ensis. This species was found only once during the sampling period, but in large quantity. It is probable, that at that time this species was migrating and was by chance captured while passing the sampling area.

The family Atherinidae is represented by a single species Pranaesus duodecimalis. MunRo (1967) stated that this species is coastal inhabitant, and that mature individuals attain a length of $100 \mathrm{~mm}$. During the sampling period, only a single mature specimen was found i.e. in February. Thus this species may comes to the area only for feeding or seeking a shelter. Similar to Paramia quinquelineata, this species lives there until reaching a certain stage of maturity, then migrates for spawning.

The family Labridae is represented by the largest number of species i.e. nine species. Of those species, Halichoeres leparensis, $H$. argus, and Stethojulis strigiventer are the most prominent species. Based on their size ranges and consistent occurrence during the observation period, they likely spend most of their lives in this area, but migrate to other places for spawning. The next important species is Choerodon anchorage. The collected specimens of this species consisted of young individuals, so it may come there for feeding only.

Family Monacanthidae found in this area consisted of five species. Monacanthus tomentosus is the most important species, also spending most of its life there but spawning in other place. The same is true for $M$. hajam, a species which is secondly important in this family. The next important species is $M$. my $H i$, which is represented only by young individuals. It is concluded that this area forms its nursery ground.

Family Gerridae is represented by a single species, Gerres macrosoma. This species lives there until adult stage, and migrates to another place for spawning. In February the juveniles occurred in a large quantity, but due to their small sizes a small number had been collected. From this fact, it is likely that spawning of this species takes place in January-February.

Three species of Siganus i.e. S. canaliculatus, S. chrysospilos, and S. virgatus are representative of the family Siganidae, of which S. canali-culatus is the most abundant species. As the collected specimens are mostly juveniles, it is assumed that these species occur in the area only as juveniles. The siganids are primarily herbivorous, grow fast and are primarily herbivorous, grow fast and are found widespread in the Indo- 
Pacific region. They have been shown to be suitable for aquaculture in Israel, Guam, Singapore, and the Philippines (SIGANID MARICULTURE GROUP 1972). Furthermore, siganids have been induced to spawn in Singapore, Israel, and Pulau (LAM 1974, SigANID MARICULTURE GROUP 1972, WILSON 1974). Among siganid species, S. canaliculatus seems to be the best candidate for aquaculture. It is now being studied intensively in Palau and Singapore. More information on its reproductive habits is more available than on any other species (WILSON 1974).

In Singapore SOH \& LAM (LAM 1974) have studied the reproductive cycle of this species, and found that the cycle is an annual one. Juveniles appear during the spawning season (March-April). These will grow rapidly to adult size by December. The gonads begin to mature rapidly, attaining full maturity by late January or February. A similar cycle has been reported for $S$. canaliculatus in the Philippines where several subsequent gonadal cycles have been observed (LAVINA \& ALCALA 1973). It appears that the spawning season of the species from the Philippines is closer to that from Singapore. Those appear to be the second but minor spawning season for this species. In Singapore waters, the juveniles are found not only in February-May but also in August-October, though in smaller quatities (LAM 1974)-. Similarly in the Philippines, the fry appear for a second season in August and September (LAVINA \& ALCALA 1973). The result of the present study seems to confirm the above findings. In the west shore of Burung Island, juveniles of $S$. canaliculatus were found in a large number in AugustOctober 1975, and in March 1976 (Fig. 7).

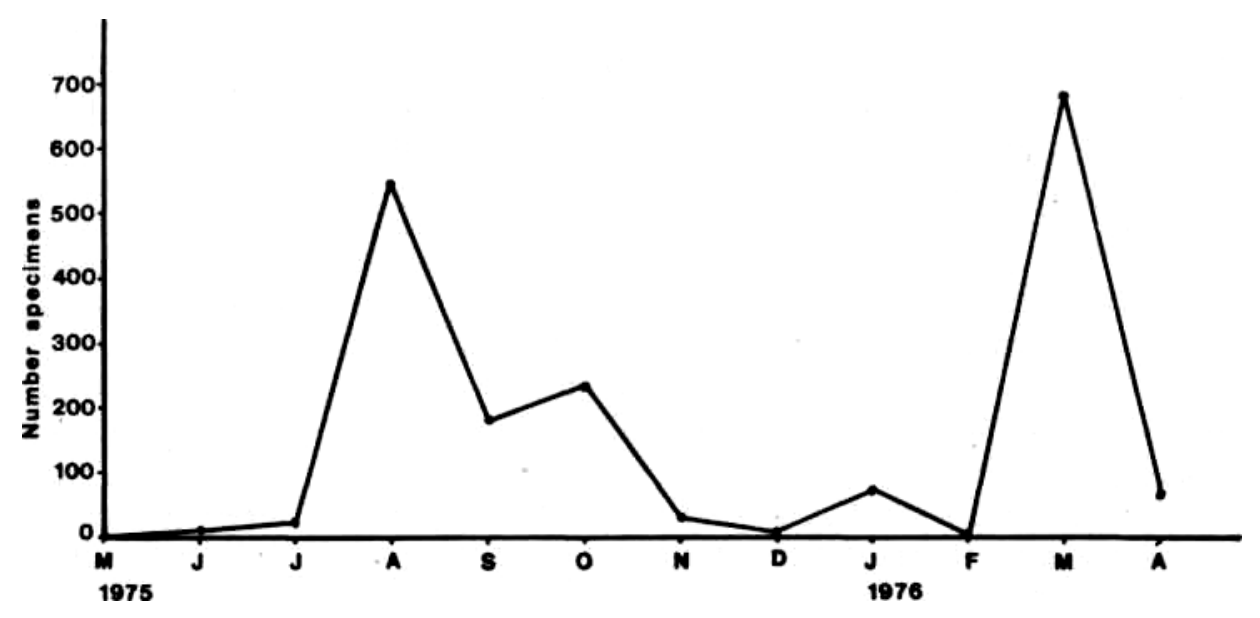

Figure 7. The variations of abundance of Siganus canaliculatus of seagrass shore on the west side of Burung Island. 
Based on their seasonal occurrence and their size ranges, the fishes of the area can be divided into four groups. Those are 1) resident, 2) resident during juveniles through adult stage but spawning elsewhere, 3) resident only during juveniles stage, 4) occasional visitors.

1) Resident. These are species which spawn and spend the greater part of their lives there. Although Apogon margaritophorus was the only species belonging to this group, it is strongly suspected that there should be other species which can be included. In this case, the limited ability of the gear used in capturing the bottom dwelling species may become a limiting factor. It is assumed that Congrogadus subducen also belongs to this group. This assumption is based on the fact that both juvenile and adult specimens have been collected, and that a spent specimen have been found during the, sampling period. Due to its eel shape, it is difficult to catch this fish, especially the juvenile ones.

2) Resident from juvenile through adult stage. These are species which spend most of their lives there, but migrate to other places for spawning. These may include :

\section{Halichoeres leparensis \\ Pranaesus duodecimalis \\ Paramia quinquelineata \\ Gerres macrosoma \\ Monacanthus tomentosus \\ Stethojulis strigiuenter \\ Monacanthus hajam \\ Syngnathoides biaculeatus \\ Hemiglyphidodon plagiometopon}

3)Resident during juvenile stage. These are species which occur in this area during their juvenile stages, namely:

Siganus canaliculatus Lethrinus spp.

Scarus spp.

Siganus virgatus

Siganus chrysospilos Choerodon

anchorago Abudefduf sp.

Monacanthus mylii Mulloides

samoensis Pelates quadrilineatus

Upeneus tragula

4) Occasional visitors. These are species which occur in this area only occasionally. Species belonging hereto do not need to be mentioned 
here since in every biological or ecological unit stragglers from elswhere can be found.

Admittedly, this classification is somewhat arbitrary because of the limited availability of the data on various stages, incomplete knowledge of life history and distribution, and the limited ability of the gear used in catching the species inhabiting this area. In the last case the authors refer to the fact that beach seine used in the sampling is not able to catch the bottom dwelling species properly. The use of other gears capable of capturing those species will give a clearer picture of the fish community of the area.

\section{ACKNOWLEDGEMENTS}

The authors are deeply indebted to Dr. APRILANI SOEGIARTO, Director of the National Institute of Oceanology, for his encouragements in this study and for the correction of the English text. Thanks are also due to Mr. DANIEL PAULY, of the Institute fur Meereskunde, Kiel, Federal Republic of Germany, who have given valuable advices and correction of the manuscript, and to Mr. SUJOTO and Mr. YAHMANTORO for their technical assistance.

\section{REFERENCES}

GOODING, R.U. 1969. Report on a preliminary survey of the Pulau Pari Group of Islands,Java sea. Seamec Biotrop coral reef project.

GUNTER, G. 1938. Seasonal variations in abundance of certain estuarine and marine fishes in Louisiana, with particular reference to life histories. Ecol. Monogr. 8(3) : 314 - 346.

HARDENBERG, J.D.F. 1931. The fish fauna of the Rokan mouth. Treubia 12(1): 81 - 165.

HARDENBERG, J.D.F. 1937. Hydrological and ichtyological observation in the mouth of Kumai river. Treubia 16(1) : 1 - 14.

KIRKMAN, H. 1975. A description of the seagrass communities of Stradbroke Island. Proc. Roy Soc. Queensland 68(21): 129 - 131.

LAM, T.J. 1974. Siganids, their biology and mariculture potential. Aquaculture 3 : 325 - 254. LAVINA, E.M. and A.C. ALCALA, 1973. Ecological Studies on Philippine siganid fishes in Southern Negros, Philippines. Abstract (No. MSS/ABS/2/1) submitted to Marine Sciences Special Symposium, Hongkong (7th - 14th December, 1973)

MUNRO, I.S.R. 1967. The fishes of New Guinea. Dept. Agr. Stock Fish., Port Moresby, 650 pp. PEARCY, W.G. and S.W. RICHARDS 1962. Distribution and ecology of fishes of the Mystic estuary, Connecticut. Ecology 43(2) : 347 - 259.

SIGANID MARICULTURE GROUP 1972. Plans for a siganid fish farming program. University of Hawaii : $1-23$.

SPRINGER, V.G. and K.D. WOODBURN 1960. An ecological study of the fishes of the Tampa Bay area. Florida St. Bd. Conserv. Mar. Lab., Prof. Paps. Ser., 1 : 1 - 104.

SPRINGER, V.G. and A.J. Me ERLEAN 1962. Seasonality of fishes on a South Florida shore. Bull. Mar. Sci. Gulf Caribbean. 12(1) : 39 - 60. 


\section{THE FISHES SEAGRASS COMMUNITY}

SMITH, J.L.B. 1961. Fishes of the family Apogonidae. Ichthyol Bull 22: 373 - 418.

WARFEL, H.F. and D. MERRIMAN 1944. Studies on the marine resources of the Southern New England.

I. An analysis of the fish population of the shore zone. Bull Bingham Ocean. Coll. 9(2): 1 - 91.

WILSON, P.T. 1974. MMDC Progress. MMDC Newsletters $4-6: 1-6$. 
Malikusworo Hutomo \& SUlarto Martosewojo

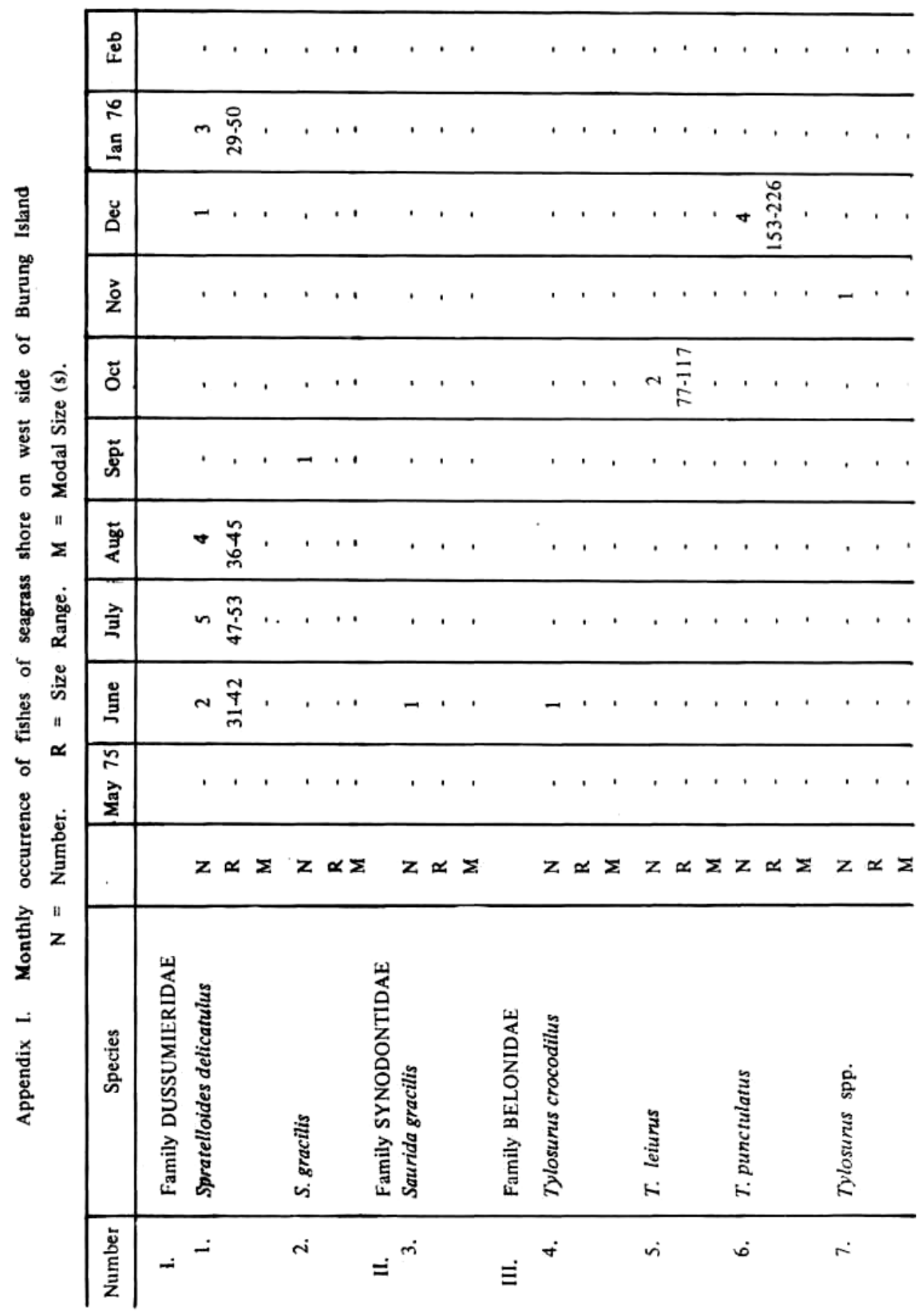


THE FISHES SEAGRASS COMMUNITY

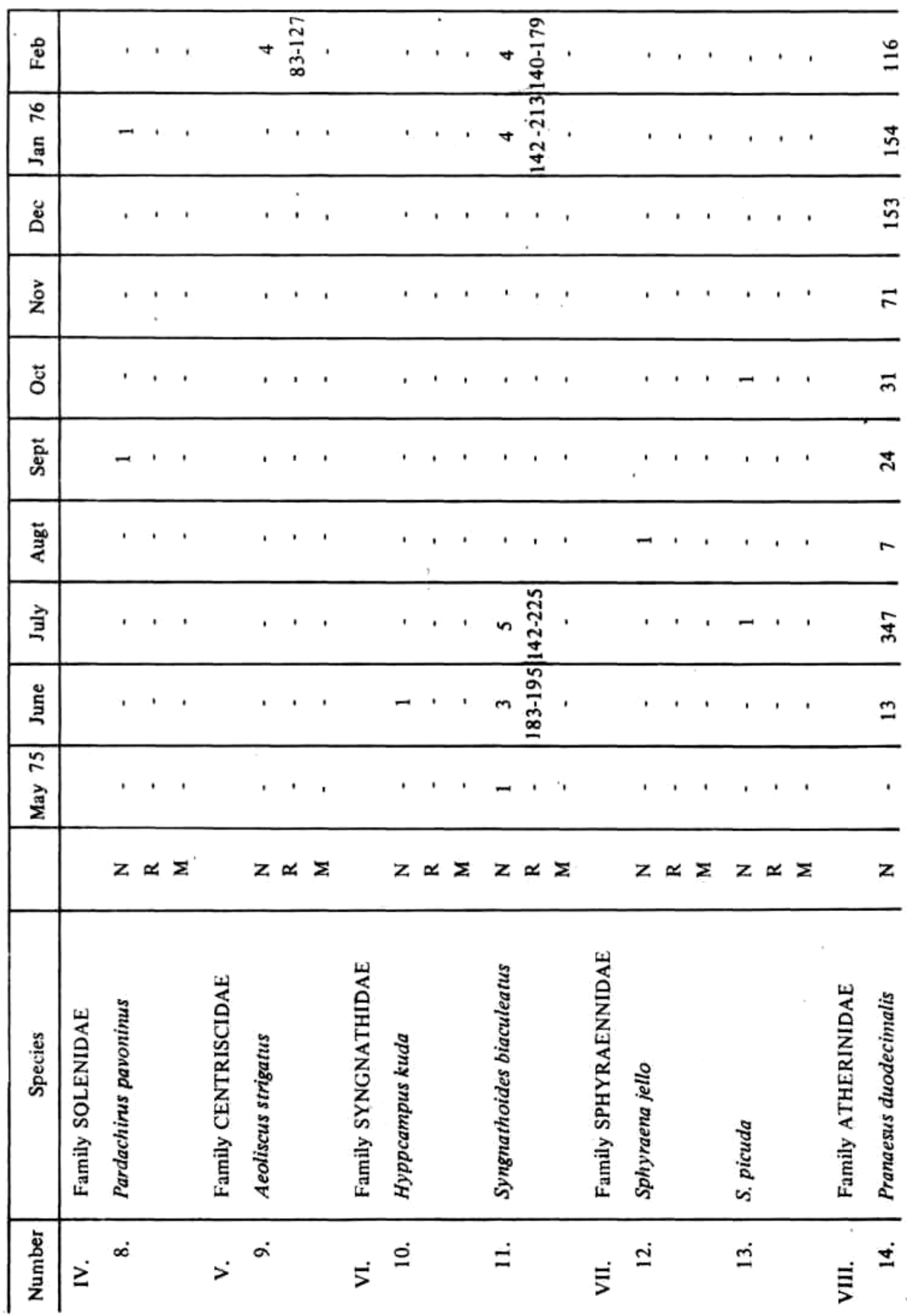


Malikusworo HUTOMo \& SUlarto MartosewoJo

\begin{tabular}{|c|c|c|c|c|c|c|c|c|}
\hline 总 & 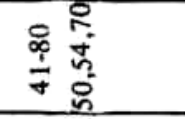 & $\cdot \cdot \cdot$ & & 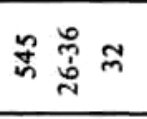 & $\cdot \cdot \cdot$ & 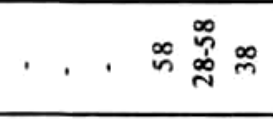 & & ' ' ' \\
\hline 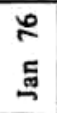 & 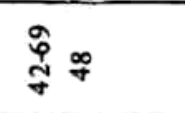 & $\cdot \cdot \cdot$ & & $\cong$ ले & . . . & 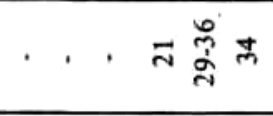 & & '. ' \\
\hline 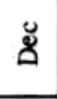 & 需葡 & . ' . & & $\stackrel{\vec{n}}{\sim} \stackrel{\infty}{\sim}$ & . ' . & . . . वิ & & . ' ' \\
\hline$\vec{z}$ & 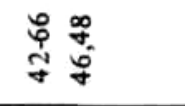 & ' ' ' & & 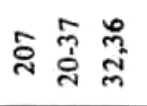 & - & . . . . '. & & . . . \\
\hline ठ & 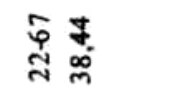 & '. ' & & $f \stackrel{n}{n}=$ & $\cdot \cdot \cdot$ & . '. & & . ' . \\
\hline 营 & 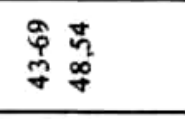 & . ' . & & 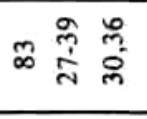 & , , ' & 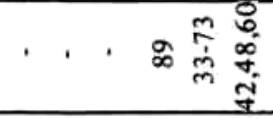 & & $\cdot \cdot \cdot$ \\
\hline 落 & 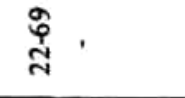 & . ' . & & 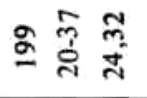 & $\cdot \cdot \cdot$ & 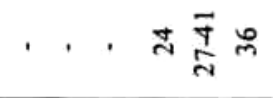 & & $-\cdots \cdot$ \\
\hline 高 & ఖ్ & . . . & & 只 六 & 卢芯苦. & 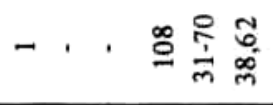 & & . ' . \\
\hline 号 & กิ & $\bar{\sim} \underset{\dot{m}}{\dot{m}} \infty$ & & $\stackrel{5}{\stackrel{5}{9}} \frac{\pi}{N}$ & . . . & 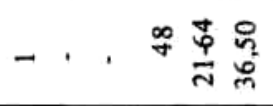 & & . . . \\
\hline \multirow[t]{2}{*}{ 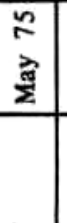 } & ' ' & . ' . & & ฟั ํํㅇ స & '. ' & , . . $\simeq \frac{\overline{\tilde{d}}}{q}$ & & $-\cdot \cdot$ \\
\hline & $\simeq \Sigma$ & $z \simeq \Sigma$ & & $z \simeq \Sigma$ & $z \approx \Sigma$ & $z \propto \Sigma z \propto \Sigma$ & & $z \propto \Sigma$ \\
\hline 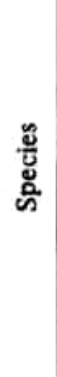 & 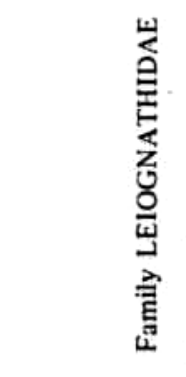 & 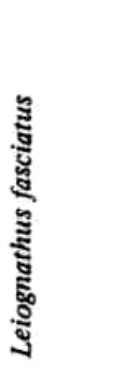 & 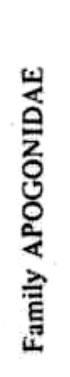 & 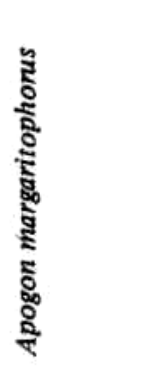 & 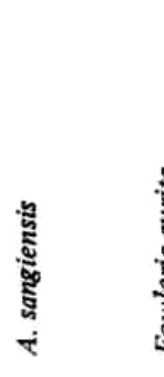 & 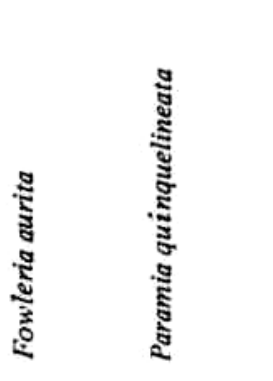 & 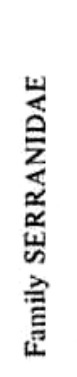 & 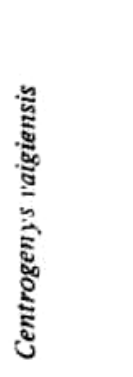 \\
\hline है & $\ddot{x}$ & $\dot{m}$ & $\dot{x}$ & $\dot{\theta}$ & $\doteq$ & $\cong$ & $\dot{\vec{x}}$ & iิ่ \\
\hline
\end{tabular}


THE FISHES SEAGRASS COMMUNITY

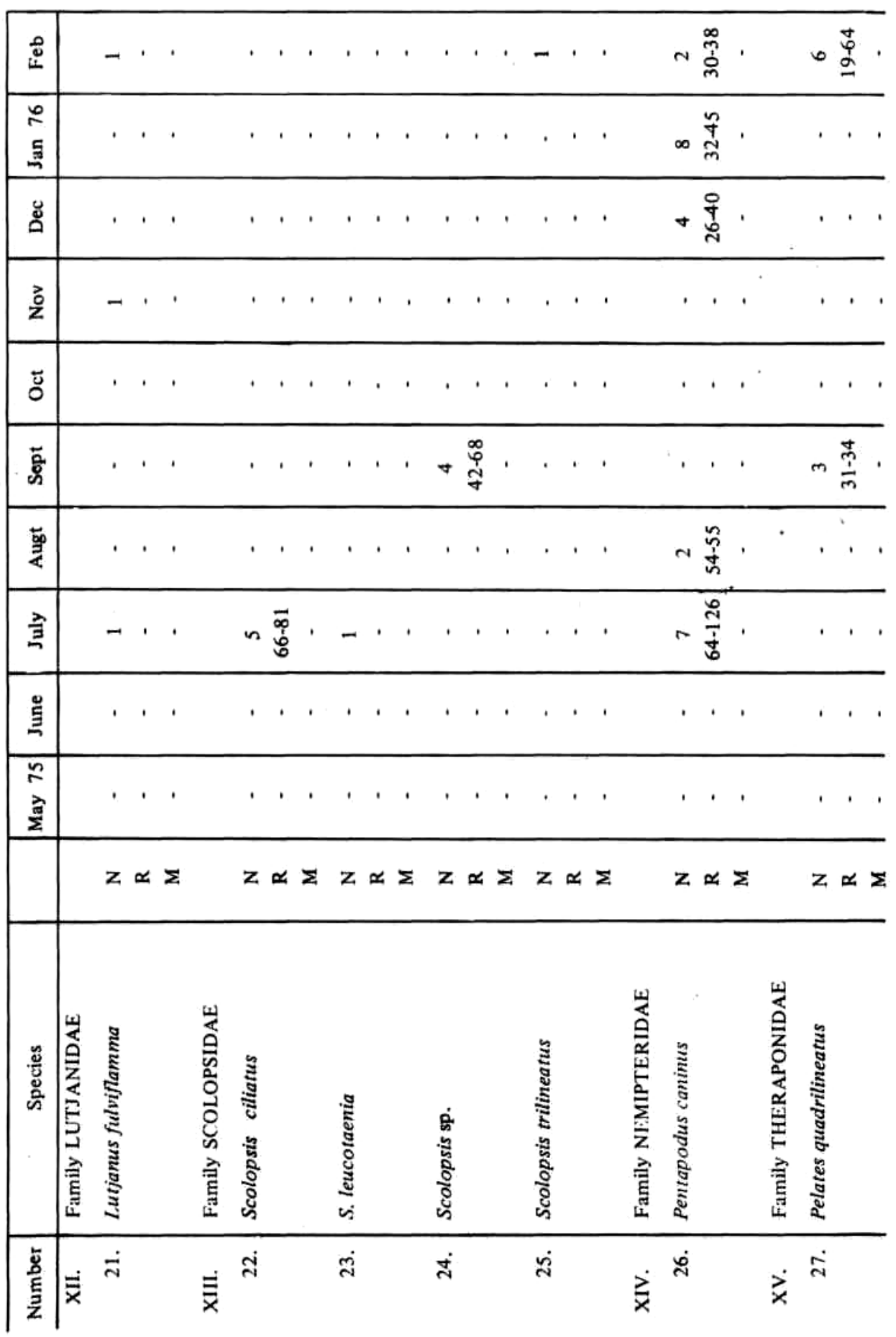


MALIKUSWORO HUTOMO \& SUlARTO MARTOSEIVOJO

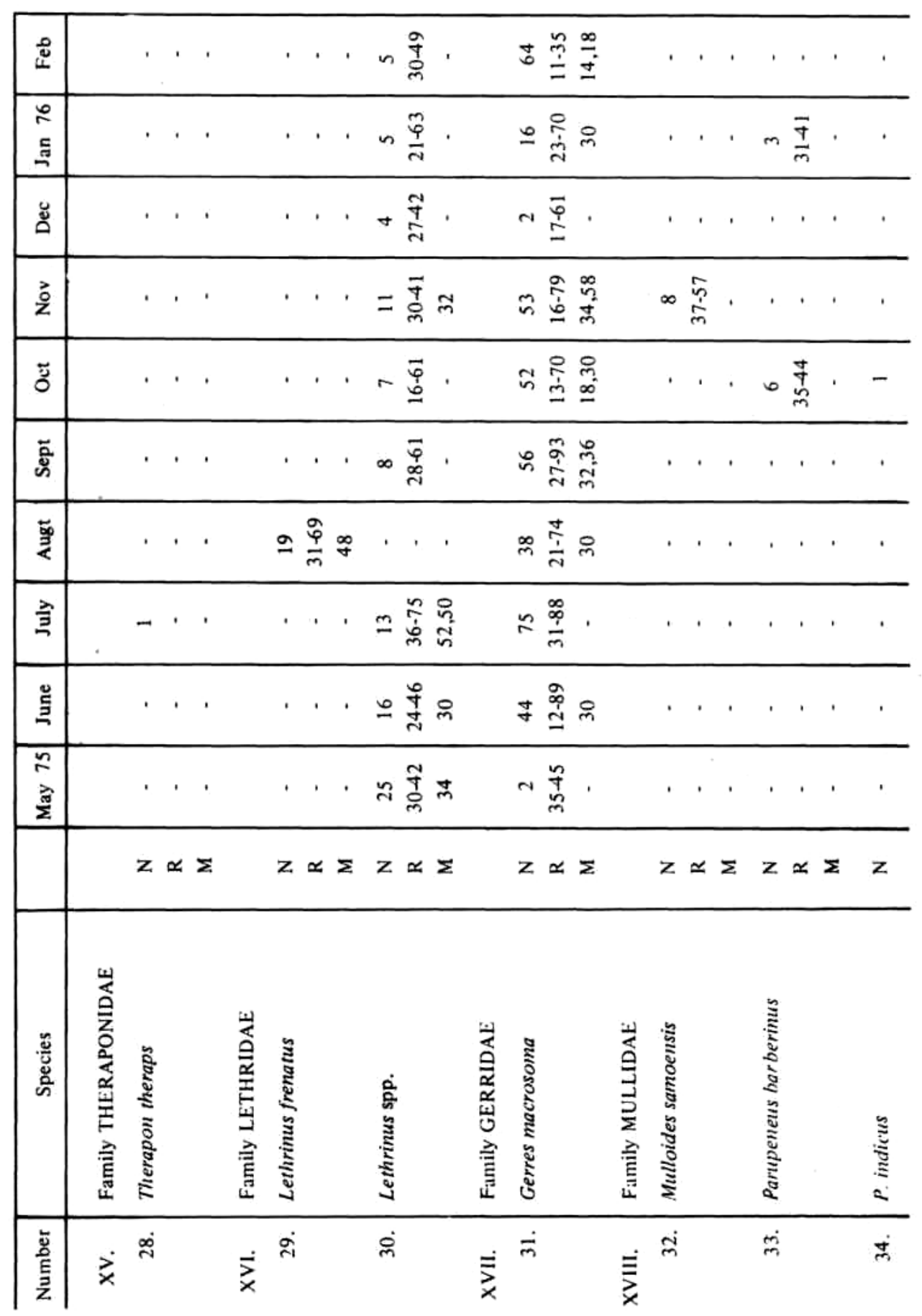


THE FISHES SEAGRASS COMMUNITY

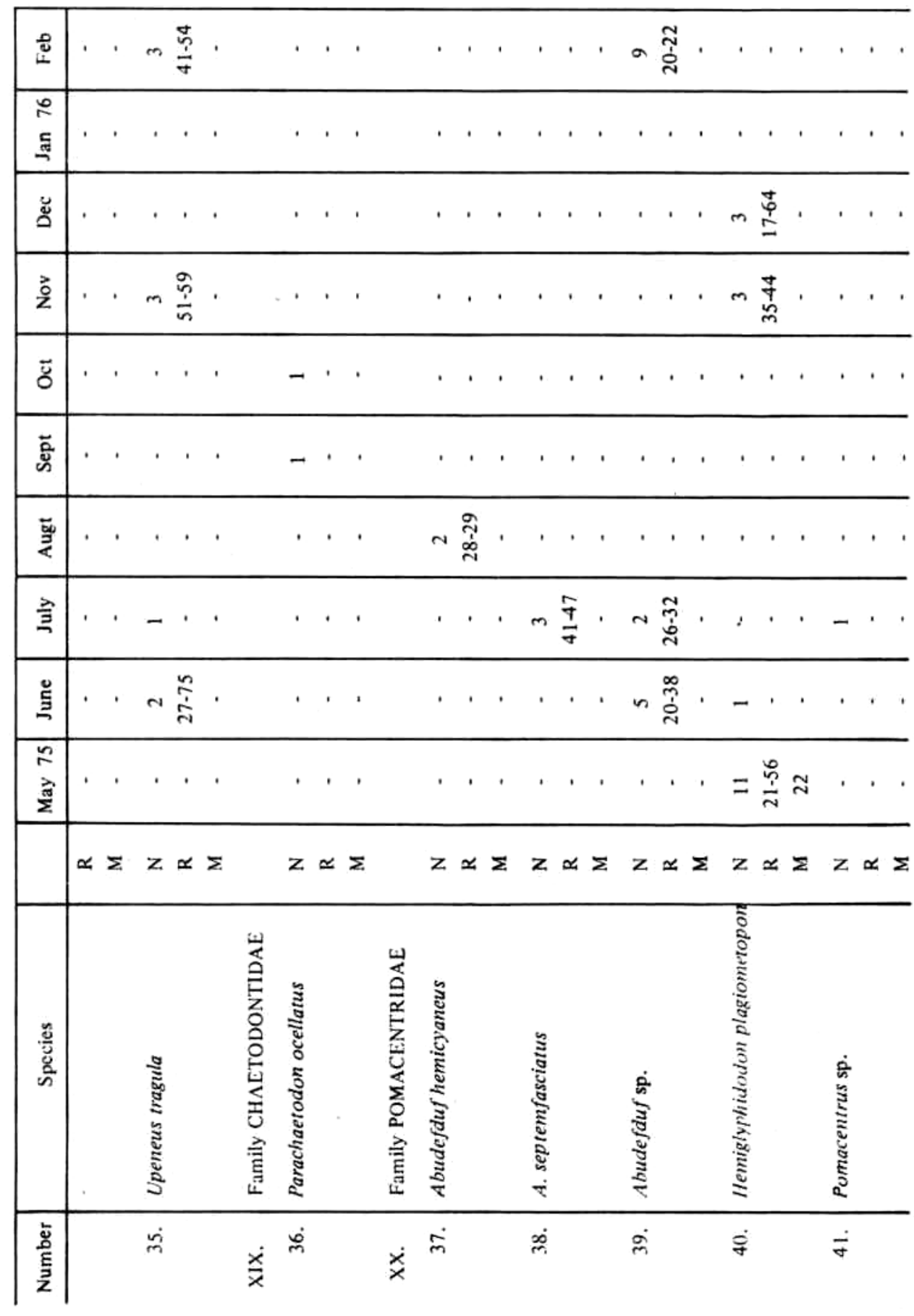


MAliKusWoro Hutomo \& SUlarto Martosewojo

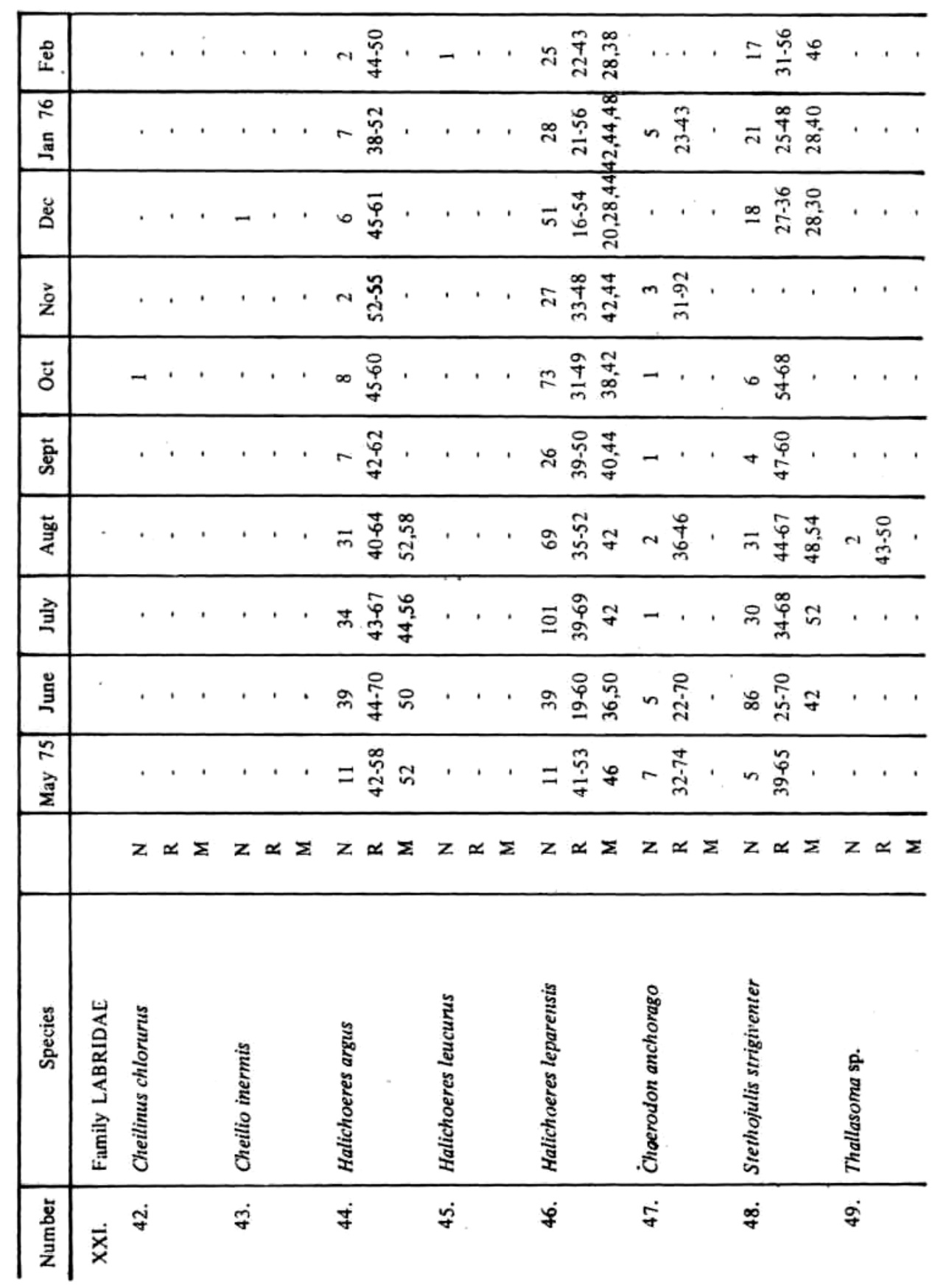


THE FISHES SEAGRASS COMMUNITY

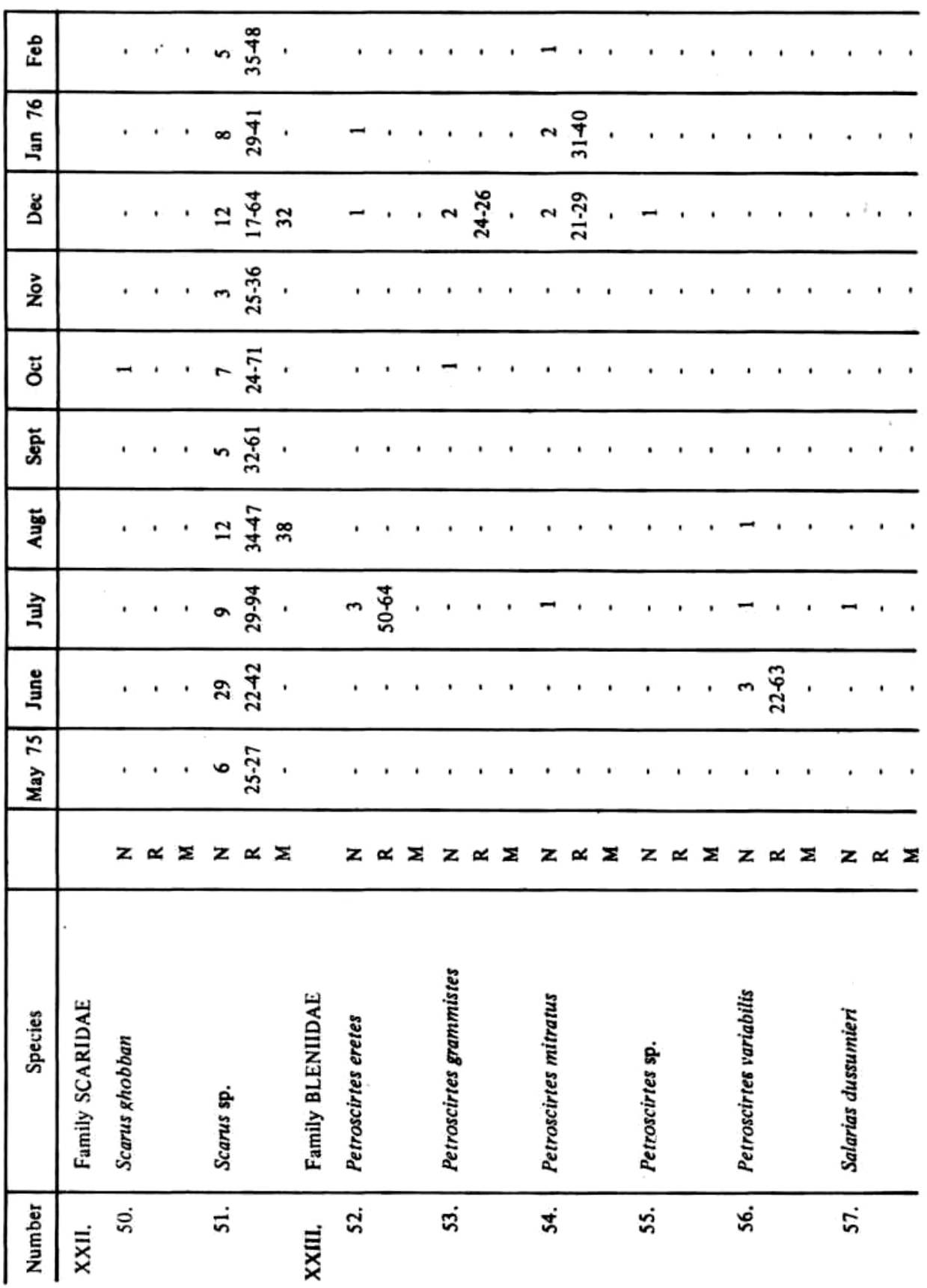


Malikusworo Hutomo \& SUlarto Martosewojo

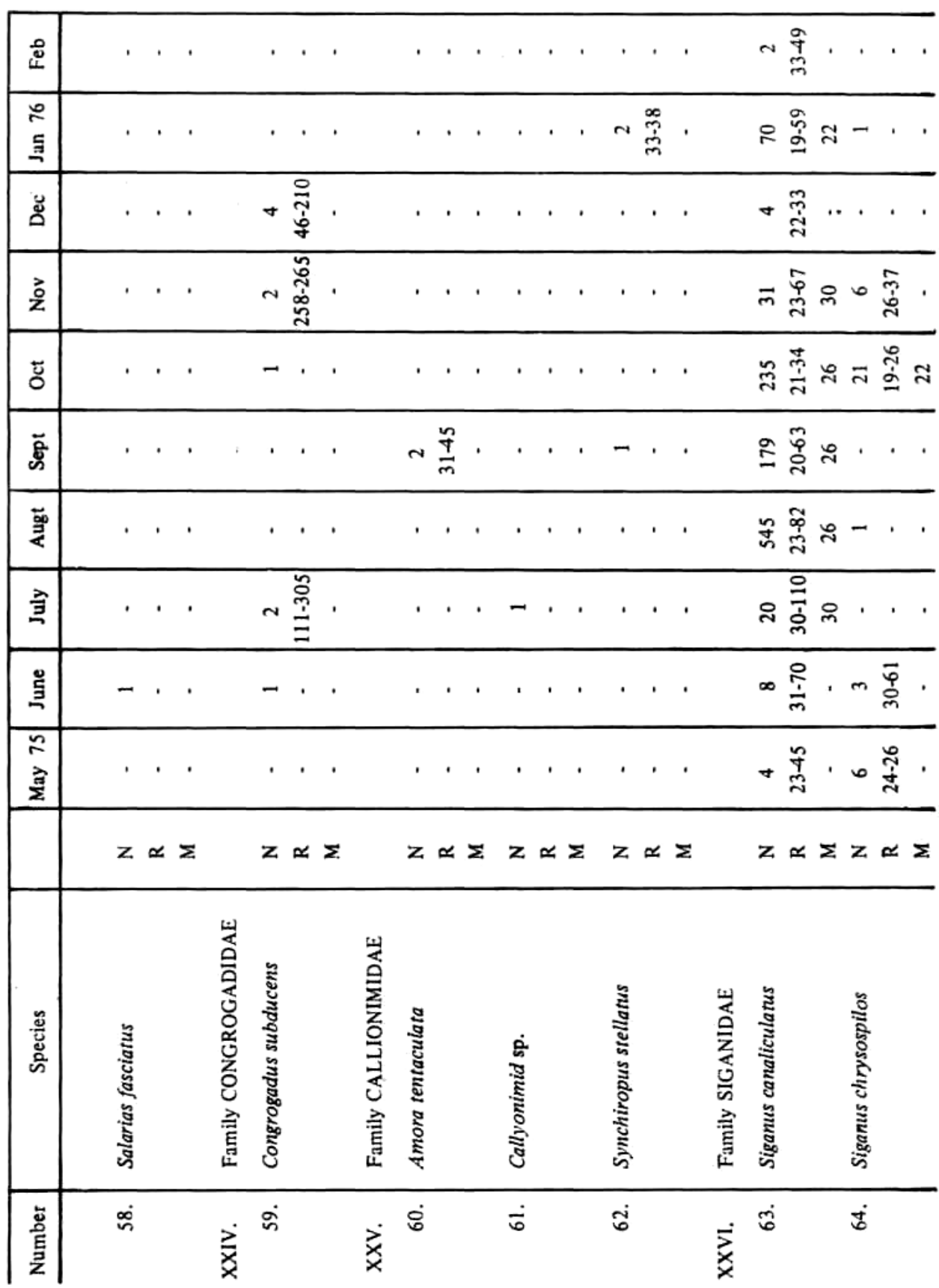


THE FISHES SEAGRASS COMMUNITY

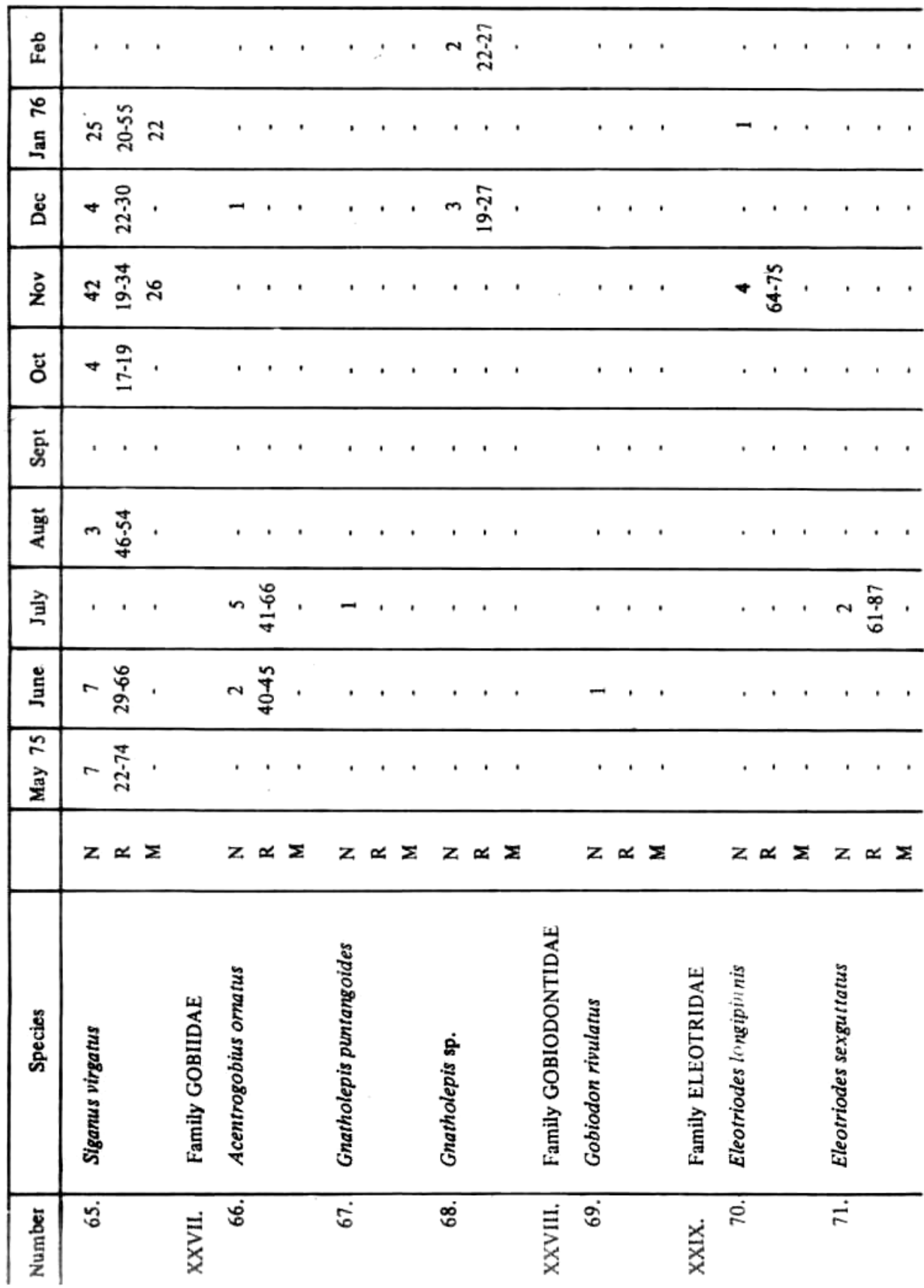




\section{Malikusworo Hutomo \& SUlarto Martosewojo}

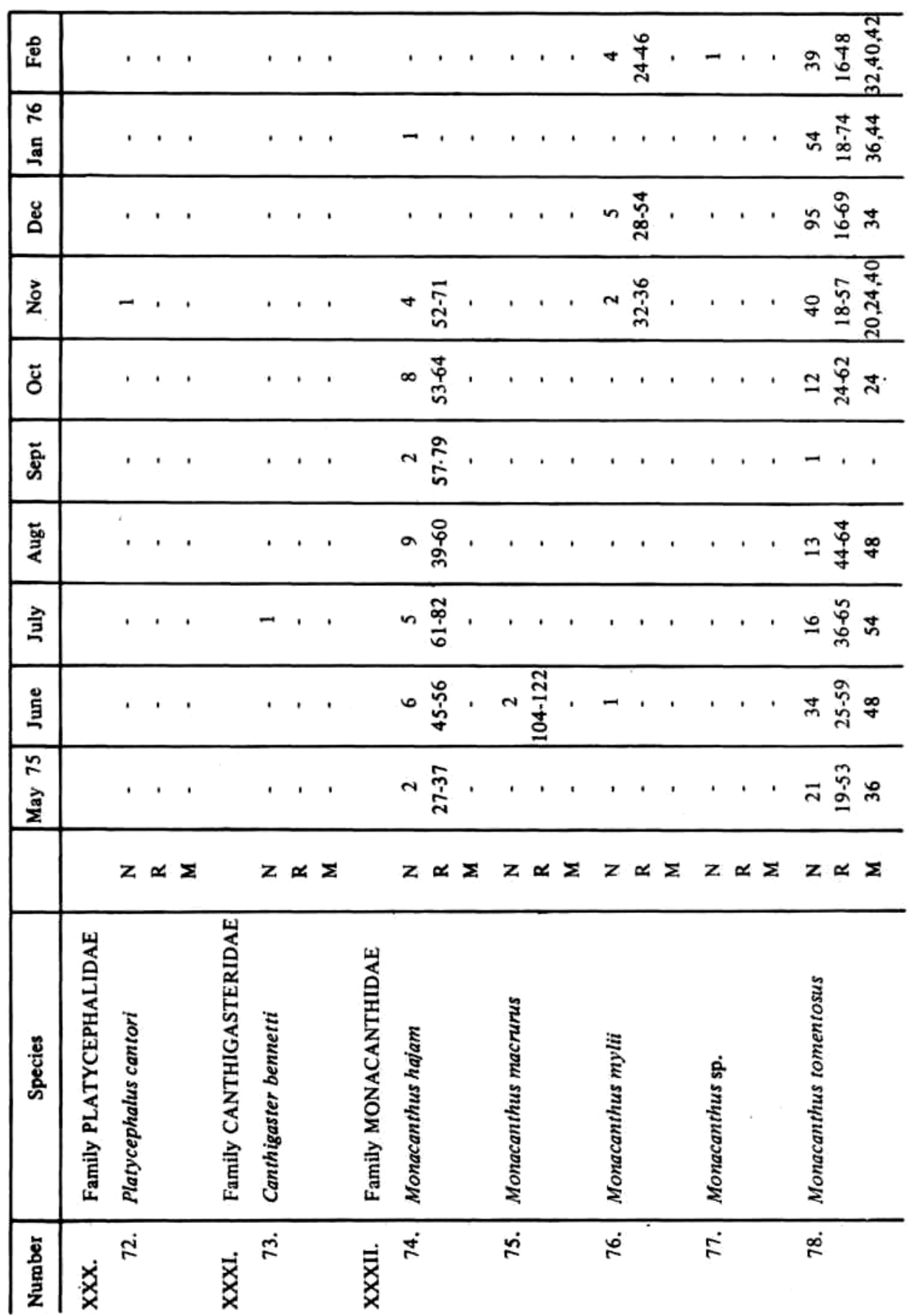

